\title{
Spuścizna prof. Marii Paradowskiej w PAN Archiwum w Warszawie Oddział w Poznaniu
}

W kwietniu 2011 r. poznański oddział Archiwum Polskiej Akademii Nauk $\mathrm{w}$ Warszawie otrzymał $\mathrm{w}$ formie darowizny spuściznę prof. Marii Paradowskiej. Spuścizna, przekazana przez Panią Katarzynę Wrzesińską, pochodzi z lat 1932-2011 i zawiera ponad cztery metry bieżące dokumentacji, rozmieszczonej w 270 teczkach, razem zajmujących 31 pudeł archiwalnych. Nieuporządkowana jeszcze spuścizna została $\mathrm{w}$ archiwum opatrzona sygnaturą P.III-151.

We wstępie warto przypomnieć postać samej prof. Paradowskiej. Maria Paradowska (ur. 1932, zm. 2011) była wybitnym etnologiem, etnografem i historykiem. Tytuł profesorski otrzymała w roku 1989. W 2004 r. została odznaczona Krzyżem Kawalerskim Orderu Odrodzenia Polski. W swoich badaniach zajmowała się przede wszystkim historią bambrów poznańskich oraz dziejami Polonii środkowo- i południowoamerykańskiej. Przez wiele lat związana była zawodowo z PAN, gdzie pełniła funkcję kierownika Instytutu Archeologii i Etnologii. Dużą popularność przyniosło prof. Paradowskiej zaangażowanie $\mathrm{w}$ organizację Towarzystwa Bambrów Poznańskich, którego była prezesem, oraz działalność na rzecz powstania Muzeum Bambrów Poznańskich. W latach 2006-2010 pełniła funkcję radnej sejmiku wielkopolskiego III kadencji z ramienia Platformy Obywatelskiej. Zebrane przez prof. Paradowską materiały stanowią bezpośrednie odzwierciedlenie jej zainteresowań badawczych.

Istotną część spuścizny stanowią materiały dotyczące wspomnianego Towarzystwa Bambrów Poznańskich, Muzeum Bambrów Poznańskich oraz samych bambrów, stąd niezbędnym zdaje się ogólne przybliżenie ich historii. 
Dzieje bambrów poznańskich sięgają początków XVIII w., konkretnie okresu wojny północnej toczącej się w latach 1700-1721. Wkroczenie armii szwedzkiej do Poznania we wrześniu 1703 r., jego późniejsze oblężenie przez zjednoczone wojska koronne, saskie i rosyjskie oraz zaraza, która nawiedziła miasto $\mathrm{w}$ roku 1708, doprowadziły do znacznego wyludnienia nie tylko samego Poznania, lecz także podpoznańskich wsi. Wobec zaistniałej sytuacji władze miasta postanowiły zapełnić miejscowości osadnikami zza zachodniej granicy. Do osadników wyznania rzymskokatolickiego w państwach niemieckich - szczególnie zamieszkujących okolice Bambergu w południowej Frankonii - skierowana została odezwa zapraszająca do osiedlenia się na opustoszałych terytoriach. Pierwsi osadnicy dotarli do Poznania w roku 1719. Przybysze zamieszkali we wsi Luboń, znajdującej się na południe od miasta. Nowi mieszkańcy otrzymali gwarancję czasowego zwolnienia z podatku, zapas ziarna oraz drewno niezbędne do odbudowy zrujnowanych domostw. Kolejne fale osadników przybywały do Wielkopolski aż do roku 1753, osiedlając się kolejno we wsiach Dębiec, Bonin, Jeżyce, Winiary, Rataje, Wilda i Górczyn, dzisiaj znajdujących się w bezpośrednich granicach miasta. Ponieważ większość nowo przybyłych mieszkańców pochodziła z Bambergu lub jego okolic, do wszystkich niemieckich osadników przylgnęło w Poznaniu miano "bambrów".

Bambrzy stopniowo wtapiali się w życie miasta. Proces ich polonizacji przybrał na sile w XIX w. Wśród pierwszych katalizatorów asymilacji należy wymienić wiarę, konkretnie chęć uczestnictwa osadników w odprawianych w języku polskim mszach i nabożeństwach katolickich. Istotny wpływ na polonizację bambrów miało także polskie szkolnictwo, zawieranie mieszanych małżeństw oraz zwykła chęć utrzymywania i poprawiania relacji sąsiedzkich z Polakami. Z czasem bambrzy wrośli na stałe w życie codzienne Poznania i Wielkopolski, czego jaskrawym przejawem była m.in. obrona polskości oraz solidaryzowanie się z miejscową ludnością podczas prowadzenia - zapoczątkowanej przez Bismarcka - polityki Kulturkampfu.

Spuściznę prof. Parandowskiej należy niewątpliwie uznać za skarbnicę wiedzy o samych bambrach i Towarzystwie Bambrów Poznańskich. Towarzystwo zostało powołane do istnienia w roku 1996. Symbolicznym rozpoczęciem jego działalności było wmurowanie 30 kwietnia w cokół pomnika bamberki na poznańskim Starym Rynku tablicy pamiątkowej informującej, że „Bamberka upamiętnia przybycie w pierwszej połowie XVIII w., na zaproszenie władz miasta, osadników z Bambergu celem odbudowy zniszczonych wojną i zarazą wsi miejskich".

W rozdziale II statutów Towarzystwa z roku 1997, które znajdujemy w przekazanych materiałach, pojawia się informacja, że „celem Towarzystwa jest:

- zachowanie i kultywowanie tradycji Bambrów Poznańskich jako integralnej części tradycji poznańskiej i wielkopolskiej, 
- ocalenie jeszcze istniejących zabytków bamberskich,

- rozwijanie zamiłowań do kolekcjonowania zabytków bamberskich oraz pamiątek rodzinnych związanych z osadnikami bamberskimi z XVIII wieku,

- odtwarzanie i uzupełnianie historii miasta Poznania związanego z osadnictwem bamberskim,

- upowszechnianie $\mathrm{w}$ społeczeństwie miasta Poznania i Wielkopolski wiedzy o osadnikach bamberskich, ich historii i działaniu na rzecz miasta, regionu, jak i całej Polski od XVIII wieku aż do dnia dzisiejszego,

- umożliwianie spotykania się potomków rodzin bamberskich i wszystkich zainteresowanych tradycją i historią Bambrów Poznańskich"1.

Badacz dziejów TBP znajdzie w spuściźnie szereg materiałów dokumentujących jego działalność, takich jak: wspomniane wcześniej statuty, sprawozdania z różnego rodzaju zebrań, rozliczenia finansowe Towarzystwa, relacje z odbywających się corocznie świąt bamberskich, ważniejszych wydarzeń, wizyt - w tym odwiedzin mieszkańców Bambergu - spotkań opłatkowych, listy członków oraz korespondencję, m.in. z władzami miasta i województwa, dotyczącą działalności stowarzyszenia.

Niezwykle cennym źródłem są cztery tomy (nr 2-5) ręcznie spisanych przez prof. Paradowską Kronik Towarzystwa Bambrów Poznańskich, które obejmują okres od 25 października 2001 r. do 14 lipca 2007 r. Kroniki są przysłowiową "kopalnią wiedzy” na temat wszelkich przejawów działalności Towarzystwa, takich jak: zebrania, korespondencja Towarzystwa, spotkania z przedstawicielami władz i wycieczkowiczami z Bambregu, udział bamberek w wydarzeniach kulturalnych oraz funkcjonowanie muzeum. Całości utrwalonych informacji nie sposób wymienić i zakwalifikować.

W brulionach formatu A4, obok spodziewanej relacji z działalności TBP, pojawiają się także subiektywne odczucia i przeżycia prof. Parandowskiej. Można stwierdzić, że kroniki mają częściowo charakter osobistych dzienników. Kroniki dają możliwość poznania prof. Paradowskiej jako człowieka, pozwalają przeanalizować, co mówiła, dlaczego mówiła, co ją denerwowało, a co cieszyło. Znajdziemy w nich liczne wzmianki dotyczące przemyśleń i życia prywatnego Paradowskiej, jej osobistych przeżyć, relacje o pogodzie oraz komentarze na temat przeczytanych artykułów prasowych.

Sporo w kronikach także materiałów nietypowych, takich jak: dziecięce laurki sporządzone jako podziękowanie za odwiedziny bamberek w szkołach, życzenia bożonarodzeniowe i wielkanocne oraz karty menu z restauracji Zagroda Bamberska, gdzie zazwyczaj TBP podejmuje gości. Ciekawym pomysłem było niewątpliwie umieszczenie w kronikach fragmentów przeciętych wstęg m.in. z uroczystości otwarcia 13 września 2003 r. nowego odcin-

${ }^{1}$ PAN Archiwum w Warszawie Oddział w Poznaniu, Spuścizna prof. Marii Paradowskiej, P.III-151, Statut TBP uchwalony przez Walne Zebranie w dniu 24.10.1997 i zatwierdzonym postanowieniem Sądu Wojewódzkiego w Poznaniu z 21 maja 1998 r., Poznań, lipiec 1998 r. 
ka podpoznańskiej autostrady oraz z oficjalnego zainagurowana działalności przez Muzeum Bambrów Poznańskich, które miało miejsce 29 listopada 2003 r. ${ }^{2}$, a któremu poświęcona jest znaczna część całej spuścizny.

Studiując materiały, można prześledzić dzieje tworzenia Muzeum od pierwszych, niezrealizowanych planów, poprzez jego budowę, wmurowanie kamienia węgielnego, aż do faktycznej codziennej działalności. Nie sposób w tym miejscu wymienić wszystkich zgromadzonych na temat placówki materiałów, stąd niezbędne stało się wybranie tylko co ciekawszych - subiektywnym zdaniem autora - materiałów.

Już w trzeciej teczce materiałów znalazły się plany Towarzystwa utworzenia przy ul. Mostowej w Poznaniu muzeum na kształt domu bamberskie$\mathrm{go}^{3}$. W ostateczności zrealizowany pomysł nie spotkał się początkowo z entuzjazmem ze strony władz miasta. Inne propozycje ulokowania muzeum przewidywały zaadoptowanie na jego potrzeby m.in. zajezdni tramwajowej przy ul. Gajowej, budynku Wagi na Starym Rynku czy starej masztarni w CK Zamek. Ze strony Prezydenta Miasta pojawiła się propozycja włączenia zbiorów bamberskich do Muzeum Etnograficznego w Poznaniu, co spotkało się z dużym rozżaleniem członków TBP. Ostatecznie podjęto decyzję o zrealizowaniu pierwotnego projektu domu bamberskiego przy ul. Mostowej.

Wśród późniejszych materiałów omawianej spuścizny znajduje się tekst aktu erekcyjnego Muzeum Bamberskiego, informujący, „iż niniejszym rozpoczynamy przedsięwzięcie wielce chwalebne i pożyteczne. Towarzystwo Bambrów Poznańskich Roku Pańskiego 2002 w miesiącu Julianem zwanym po polsku lipcem dnia 6-tego w sobotę [...] uczyniło pierwszy krok ku wybudowaniu przybytku, który by służył jako schronienie i na pokaz statkom, meblom i ubiorom dającym świadectwo narodzinom, życiu i sławie Bambrów, którzy przybywając do miasta Poznania roku 1719 z Bambergu z krainy wówczas Frankonią zwaną dobry i zły los dzielący z mieszkańcami tego grodu"4.

Sam proces budowy Muzeum również został dobrze udokumentowany. W materiałach znajdziemy m.in. zgodę na inwestycję od Konserwatora Miejskiego, wnioski o różnego rodzaju przetargi oraz projekty placu budowy. Samemu otwarciu Muzeum, które - jak już wspomniano - miało miejsce pod koniec listopada 2003 r., Maria Paradowska poświęciła piętnaście stron szczegółowej relacji w Kronice Towarzystwa Bambrów Poznańskich, rozpoczynającej się słowami: „Nareszcie nadszedł ten oczekiwany moment. Namiot pełen ludzi" ${ }^{5}$. Informacje o otwarciu Muzeum znajdują się także w Sprawozdaniu merytorycznym z działalności TBP za rok 2003, gdzie wymienia się gości ho-

\footnotetext{
2 Tamże, Kronika TBP: 26 X 2001 - 31 XII 2003.

${ }^{3}$ Tamże, pismo do wiceprezydenta Frankiewicza z 27 sierpnia 2001 r.

${ }^{4}$ Akt erekcyjny Muzeum Bamberskiego w Poznaniu, 6 lipca 2002 r.

${ }^{5}$ PAN Archiwum w Warszawie Oddział w Poznaniu, Spuścizna prof. Marii Paradowskiej, P.III-151, Kronika TBP: 26 października 2001 r. - 31 grudnia 2003 r.
} 
norowych przybyłych na uroczystość, w tym: władze miejskie, wojewódzkie, parlamentarzystów, duchowieństwo, ambasadora RP w Niemieckiej Republice Federalnej, samych członków Towarzystwa BP, a także przedstawicieli władz miasta Bamberg. W sprawozdaniu utrwalono m.in. słowa ambasadora Andrzeja Byrta, który stwierdził, że Muzeum jest „domem przyjaźni Polaków i Niemców, z którego Europa winna brać przykład”"

$\mathrm{W}$ zachowanych $\mathrm{w}$ spuściźnie wypisach $\mathrm{z}$ księgi muzealnej pod datą 29 listopada 2003 r. znalazły się m.in. wpisy Prezydenta Miasta Poznania Ryszarda Grobelnego („Gratulacje, gratulacje, gratulacje... Życzenia, życzenia, życzenia...") oraz Wojewody Wielkopolskiego Andrzeja Nowakowskiego („Muzeum znacznie wzbogaca mapę kulturalną Poznania, szczególnie tuż przed akcesją z Unią Europejską...”). W późniejszych wpisach zwiedzających nie brakuje ciepłych słów, słów zachwytu, życzeń powodzenia oraz podziękowań za „ocalenie od zapomnienia i udostępnienie zwiedzającym części historii miasta Poznania".

Sporo miejsca poświęca prof. Paradowska problemom finansowym, z jakimi borykało się TBP podczas realizacji przedsięwzięcia tworzenia Muzeum. W licznych sprawozdaniach, protokołach oraz korespondencji z władzami miasta i województwa zauważalne jest rozczarowanie stale malejącą ${ }^{7}$ zdaniem TBP-pomocą materialnąi zainteresowaniem miasta całym przedsięwzięciem, pogłębiające się wraz z narastającym zadłużeniem Muzeum. W protokole z Walnego Zebrania Sprawozdawczo-Wyborczego Towarzystwa Bambrów Poznańskich z 25 kwietnia 2008 r. znajdujemy informację, że „Miasto nie doceniło i w dalszy sposób nie docenia naszej placówki [Muzeum Bambrów Poznańskich]"8. Niektóre utrwalone w protokole wzmianki zdają się wyraźnie potwierdzać nikłą troskę władz miasta o Muzeum: „14 stycznie br. nadburmistrz Bambergu przesłał do Prezydenta Miasta Poznania Pana Ryszarda Grobelnego list $\mathrm{z}$ ofertą pomocy $\mathrm{w}$ naszych trudnościach. Towarzystwo po otrzymaniu kopii odpowiedziało natychmiast na ten list, a Pan Prezydent po 3 miesiącach". Problem finansowania placówki był tym bardziej dotkliwy, że utrzymanie Muzeum i działalność TBP opierały się głównie na darowiznach, zbiórkach pieniężnych prowadzonych przez bamberki i zbiórkach do skarbonki znajdującej się w Muzeum. Biorąc pod uwagę okresowość funkcjonowania placówki, działającej tylko w sezonie letnim, oraz niezbyt wy-

\footnotetext{
${ }^{6}$ Tamże, Sprawozdanie merytoryczne z działalności TBP za rok 2003, s. 2.

${ }^{7}$ Na budowę Muzeum miasto wyłożyło blisko 800 tys. zł, co stanowiło połowę kosztów całego przedsięwzięcia.

${ }^{8}$ PAN Archiwum w Warszawie Oddział w Poznaniu, Spuścizna prof. Marii Paradowskiej, P.III-151, Protokół z Walnego Zebrania Sprawozdawczo-Wyborczego Towarzystwa Bambrów Poznańskich, 25 kwietnia 2008 r., s. 5.

${ }^{9}$ PAN Archiwum w Warszawie Oddział w Poznaniu, Spuścizna prof. Marii Paradowskiej, P.III-151, Sprawozdanie Komisji Rewizyjnej Towarzystwa Bambrów Poznańskich za okres 27.02.2004-25.04.2008, Poznań 25 kwietnia 2008 r.
} 
soką liczbę odwiedzających (pod datą 1 lipca 2006 r. w Kronice TBP znajdujemy informację: „nikt nie przyszedł zwiedzać. To chyba po raz pierwszy!!"10), wsparcie finansowe z zewnątrz było Muzeum nadzwyczaj potrzebne, a jego brak doprowadził ostatecznie do rozpraw sądowych i rozmów z komornikiem, o czym wzmianki znajdują się zarówno w korespondencji, jak i w sprawozdaniach oraz Kronikach TBP. Pomysł miasta, by oddać Muzeum Bambrów Poznańskich pod opiekę Muzeum Narodowego, nie spotkał się z pozytywnym przyjęciem ze strony członków TBP, obawiających się utraty siedziby oraz ewentualnych roszczeń ze strony Muzeum Narodowego.

Kolejna część materiałów poświęcona jest organizowanym corocznie w pierwszą sobotę po 1 sierpnia Świętom Bamberskim, które zapoczątkowano w roku 1996. Data wydarzenia nie jest przypadkowa. 1 sierpnia 1719 r. została podpisana pierwsza umowa (której tekst znajdziemy w materiałach zebranych przez prof. Paradowską) między przybyłymi do wsi Luboń bambrami a miastem Poznań. Od roku 2000 w ramach obchodów Święta TBP przyznaje osobom zasłużonym dla Towarzystwa odznakę Złotej Bamberki. Dokumentacja dotycząca kolejnych Świąt jest obszerna, jednak dość rozproszona. W spuściźnie znajdą się okolicznościowe przemówienia prof. Paradowskiej i ważniejszych gości, liczne plany, relacje, sprawozdania oraz zdjęcia upamiętniające coroczne obchody.

Inne materiały dotyczące bambrów zawarto w zgromadzonych przez prof. Paradowską artykułach z najróżniejszych gazet ogólnopolskich i regionalnych, własnoręcznie pisanych przez prof. Paradowską pracach i przemówieniach okolicznościowych, drzewach genealogicznych wybranych poznańskich bambrów, a nawet pamiątkach tak szczegółowych, jak opis przekazywanych do Muzeum Bambrów Poznańskich eksponatów. Jako ciekawostkę można uznać znajdujący się w spuściźnie rękopis wydanej w 2003 r. książki Marii Paradowskiej O historii Bambrów inaczej ze sporządzonymi przez autorkę szkicami ilustracji.

Kolejną, choć już mniej liczną część materiałów stanowią informacje dotyczące życia Polonii latynoamerykańskiej. Z wybranych artykułów, nierzadko przekazanych prof. Paradowskiej korespondencyjnie, można odtworzyć działalność instytucji polonijnych oraz zapoznać się z warunkami panującymi w poszczególnych krajach Ameryki Południowej. Ciekawym źródłem są listy wysłane do prof. Paradowskiej w latach osiemdziesiątych i dziewięćdziesiątych, w których znajdziemy liczne opisy życia codziennego Polaków oraz pogłębiającego się kryzysu m.in. w Argentynie, Brazylii, Urugwaju, Kolumbii, Meksyku i Wenezueli. Materiały te dają także możliwość spojrzenia oczami emigrantów na współczesną i dawniejszą sytuację polityczną w Polsce.

Wśród dokumentacji dotyczącej Polonii wyróżniają się materiały dotyczące życia i działalności ks. Ignacego Posadzego, pierwszego przełożonego

${ }^{10}$ Tamże, Kronika TBP: 18 listopada 2005 r. - 14 lipca 2007 r. 
Towarzystwa Chrystusowego dla Polonii Zagranicznej. W spuściźnie znajdziemy relacje z licznych podróży ks. Posadzego do Rzymu, Ziemi Świętej, Egiptu, Ameryki Południowej, Francji, Danii i Polski oraz artykuły o księdzu zebrane przez prof. Paradowską. Warto wspomnieć, że zainteresowanie Paradowskiej postacią ks. Posadzego zaowocowało wydaniem w roku 1998 książki pt. Wszystko dla Boga i Polonii. Życie i działo ks. Ignacego Posadzego, której ręczny brudnopis zachował się w spuściźnie.

Pośród wartych odnotowania materiałów, niedających się zakwalifikować do żadnej z wcześniej wymienionych grup, trzeba wymienić zachowane przez prof. Paradowską gazety z 1956 r.: "Gazetę Poznańską" z 30 czerwca i 1 lipca, "Głos Wielkopolski” z 30 czerwca i 1-2 lipca, "Trybunę Ludu” z 30 czerwca, zawierające sprawozdania z tzw. wydarzeń czerwcowych, w tym przemówienie Józefa Cyrankiewicza po wydarzeniach $w$ Poznaniu ${ }^{11}$ oraz relację z pogrzebu "ofiar poległych w czasie krwawych zajść, wynikłych z faszystowskich prowokacji” ${ }^{12}$. Obok prasy z roku 1956 znalazł się także „Kurier Szczeciński" z 20 grudnia 1970 r., relacjonujący strajki stoczniowców.

Podsumowując, przekazana do archiwum PAN spuścizna stanowi przede wszystkim niezwykle cenne źródło do badań dziejów poznańskich bambrów, Towarzystwa Bambrów Poznańskich oraz Muzeum Bamberskiego. Zawarte $\mathrm{w}$ materiałach relacje z codziennej działalności TBP, organizacji Świąt Bamberskich, procesu budowy Muzeum oraz licznie zebrane dokumenty, artykuły i notatki na temat bambrów są bez wątpienia ciekawym materiałem, rzucającym nowe światło na wiele zagadnień związanych z działalnością samego Towarzystwa. Spuścizna może także zainteresować osoby zajmujące się badaniami Polonii żyjącej w Ameryce Środkowej i Południowej, w tym m.in. życiem i działalnością ks. Ignacego Posadzego. Na koniec, trzeba wspomnieć, że zebrany materiał jest także niezwykle interesujący przez wzgląd na samą postać prof. Marii Paradowskiej, której ogromna wiedza i zaangażowanie zarówno w propagowanie wiedzy o bambrach, jak i różnego rodzaju działalność publiczną nie mogą pozostać niezauważone.

11 PAN Archiwum w Warszawie Oddział w Poznaniu, Spuścizna prof. Marii Paradowskiej, P.III-151, "Głos Wielkopolski”, 20 czerwca 1956.

12 PAN Archiwum w Warszawie Oddział w Poznaniu, Spuścizna prof. Marii Paradowskiej, P.III-151, „Głos Wielkopolski”, 1/2 lipca 1956. 
Zuzanna Jaśkowska

\title{
Spuścizna prof. Marii Paradowskiej w PAN Archiwum w Warszawie Oddział w Poznaniu
}

\begin{abstract}
Streszczenie
W artykule omówiono spuściznę zmarłej w 2011 r. prof. Marii Paradowskiej, długoletniej kierownik Instytutu Archeologii i Etnologii PAN. W poszczególnych paragrafach przedstawiono rodzaje dokumentacji przekazanej do zbiorów PAN Archiwum w Warszawie Oddział w Poznaniu. Najwięcej miejsca poświęcono materiałom o szeroko pojętej tematyce Bambrów, w tym działalności Towarzystwa Bambrów Poznańskich, organizacji corocznego Święta Bamberskiego oraz budowie i funkcjonowaniu otwartego w 2003 r. muzeum zadedykowanego tej społeczności. Kolejna część tekstu skupia się na zebranej przez prof. Paradowską dokumentacji, dotyczącej Polonii latynoamerykańskiej. W grupie tej wyróżniają się materiały na temat życia i działalności ks. Ignacego Posadzego, pierwszego przełożonego Towarzystwa Chrystusowego dla Polonii Zagranicznej. Artykuł, poprzez analizę spuścizny, przybliża zainteresowania badawcze oraz postać samej prof. Paradowskiej.
\end{abstract}

\section{The Heritage of Professor Maria Paradowska in the Polish Academy of Sciences in Warsaw, Poznan Branch}

\begin{abstract}
The article discusses the heritage of the late professor Maria Paradowska (died in 2011), longserving head of the Institute of Archeology and Ethnology of the Polish Academy of Sciences. Each paragraph presents types of documents conveyed to the collection of the Polish Academy of Sciences in Warsaw, Poznań branch. Here, the most broadly discussed are the publications on the Bamberg settlers in Poznań, including materials on the Society of Poznań Bamberg Settlers, the annual organization of the Bamberg Festival, and the creation and operation of the museum dedicated to the Bamberg community in Poznań (opened in 2003). The next part of the text focuses on documentation on Polish emigrants in Central America, gathered by prof. Paradowska. In this group, the materials on life and work of father Ignacy Posadzy (the first superior of the The Society of Christ Fathers for Poles Living Abroad) clearly stand out. The analysis of prof. Paradowska's heritage reveals not only her research areas, but also her character.
\end{abstract}

